\title{
Obituary: Professor Ilya I. Blekhman (29 November 1928-03 February 2021)
}

\author{
Katica (Stevanović) Hedrih • Alexander Fidlin • Konstantin Lurie • \\ Giuseppe Rega $\cdot$ Lutz Sperling
}

(C) Springer Nature B.V. 2021

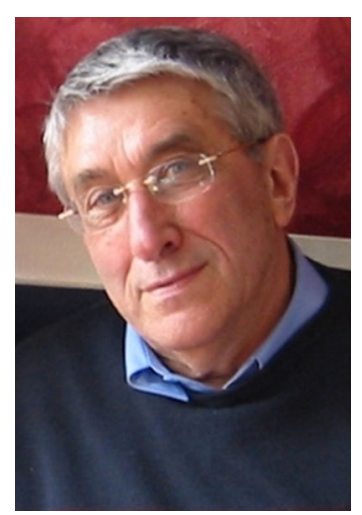

Art, before you give a man wings to soar aloft, he could usually break his leg. Charles Spencer Chaplin A letter to his daughter Geraldine, December 1965

K. (Stevanović)Hedrih

Mathematical Institute of Serbian Academy of Science and Arts, Nis, Serbia

e-mail: katicahedrih@gmail.com; katicah@mi.sanu.ac.rs

\section{A. Fidlin $(\bowtie)$}

Karlsruhe Institute of Technology, Karlsruhe, Germany

e-mail: alexander.fidlin@kit.edu

K. Lurie

Worcester Polytechnic Institute, Worcester,

MA, USA

e-mail: klurie@wpi.edu
Professor Ilya Blekhman, an outstanding scientist, a profound thinker, an extraordinary mentor, and simply a wonderful person, has left us on February 3rd at the age of 92 . He was a person who was able to recognize behind occasional observations the fundamental laws of nature, which are valid for technical devices, planets of the solar system, and biologic populations, all that merely using the power of his thoughts, intuition, and imagination. Professor Blekhman was also able to excite and inspire people, to infect them with his enthusiasm, teaching to see in small things the breath of the universe. In this sense, he was an ingenious mentor. Happy are those who knew him personally, the more so who could call him their friend or teacher. But likewise, those who had only read his scientific or popular books couldn't resist the attraction field of his unique personality. Nobody had left this field voluntarily.

G. Rega

Sapienza University, Rome, Italy

e-mail: giuseppe.rega@uniroma1.it

L. Sperling

Otto-Von-Guericke University, Magdeburg, Germany

e-mail: sperling.md@arcor.de 


\section{A short biography}

Ilya Blekhman was born in Kharkov, USSR (today Kharkiv, Ukraine) on 29 November 1928. His family moved to Leningrad (today St.-Petersburg, Russia) two years later. He had finished his 5th grade in May 1941, just before the German troops crossed the border of the Soviet Union. The Blekhman family remained in the sieged Leningrad. His father and grandmother starved to death, together with many hundred thousand civilians in the city. As for perishing Ilya, he was evacuated with his mother via the "the road of life" (on the melting ice of the Ladoga lake) in the spring of 1942. He was brought to Caucasus first and then to the Ural region, not far from the city of Sverdlovsk (today Yekaterinburg, Russia). Ilya Blekhman graduated from the high school in 1945 and right after that started his studies at the Ural Industrial Institute (Technical University). His outstanding aptitude was noticed already after the first few months; he was rewarded with additional food stamps (people were still starving in the Soviet Union), and his mother got a special letter from the dean of the faculty appreciating her efforts in having grown up such a talented son. One of Ilya's professors in Sverdlovsk was R.L. Malkina, the wife of the outstanding specialist in oscillations theory I.G. Malkin. This acquaintance opened the entrance to the Malkin's house for young Blekhman. The theory of self-synchronization of rotating bodies that Blekhman established later was significantly based on the Malkin's results on the general theory of stability.

After finishing the second year, Ilya Blekhman left Sverdlovsk and moved to Leningrad, where he continued his studies at the Leningrad Polytechnical Institute (Technical University). According to the memoirs of his fellow student V.A. Bykov, young Blekhman motivated his decision to move to Leningrad as follows: "I want to learn from Loitsyanski and Lurie themselves and not only from their books!" And his wish was fulfilled. He became a student of professor Anatoly I. Lurie-an outstanding scientist and teacher with encyclopaedic knowledge of mechanics in all its facets. There Ilya Blekhman also met his future mentor and co-author of his first book [1], professor G.Yu. Dzhanelidze. However, another encounter was probably even more important: he got to know and fell in love with Nina Leonidovna Granat who became his intimate person and wife.
Following prof. Dzhanelidze recommendation, Ilya Blekhman, still being a student, started his cooperation with the Institute of Mechanical Ore Processing "Mekhanobr". Despite this cooperation and the fact that Blekhman and his wife obtained Diploma with distinction, the state authorities had sent them both to an aircraft production plant in a workers' settlement Semionovka (today a town Arsenjev, Russia), $250 \mathrm{~km}$ away from Vladivostok in the Russian far east. Only in the fall of 1951 the young family expecting their first child managed to return to Leningrad, where Blekhman was hired as an engineer in the Mekhanobr's trial workshop. It was just the beginning of the fruitful career at this institute, where he continued to work for the next 70 years. Within two years he was promoted to the head of the experimental production. However, he was not satisfied with the content and character of that job. Soon Blekhman was transferred to the design department.

While working at the design department, Blekhman had read a technical report written by two Mekhanobr employees I.M. Abramovich and D.A. Pliss, describing how they had accidentally observed the effect which later was called "vibrational support of rotation". During testing of a vibrational conveyor with two independent inertial exciters, one of the electric motors was unintentionally disconnected from the power source. Nevertheless, both exciters remained rotating, and the conveyor was operating properly as if nothing happened. This occasional observation started the whole series of investigations by Blekhman and his colleagues, which resulted in the discovery of the selfsynchronization of rotating bodies, i.e. their ability to find a joint rhythm of movements. It occurs to be one of the most important mechanisms of self-organization of matter, which opposes the general tendency of increasing chaos [2, 10, 23, 25-28].

In parallel with exploring and analysing the selfsynchronization effect, Blekhman led the foundations of the theory of vibration-induced transportation [1, 22, 24, 29]. (Vibration-induced transportation is an approach enabling to transform a non-directed excitation into directed motion of an object.) That research had a pronounced applied character from the very beginning and was aimed towards the development of calculation methods for design of vibration conveyors and screens, and increase in their productivity. It was found out later that the discovered transformation mechanisms are very general, and thus, 
their understanding is quite important for different areas of mechanics, physics, and automated control.

Ilya Blekhman successfully defended his $\mathrm{PhD}$ thesis in 1955 and Dr. Sci. thesis in 1962. A large group of vibration-based machines using self-synchronization principle were developed and brought to series production in 60s. Blekhman's scholars and colleagues, outstanding design engineers, professor Boris P. Lavrov and professor Leonid A. Vaisberg played a crucial role in the practical realization of these ideas. In the same time period, Ilya Blekhman had organized the calculation department, which he headed in the following decades. (This department was integrated in the structure of the Institute of the Problems in Mechanical Engineering of the Russian Academy of Sciences in 1996.) A unique cluster of researchers was born. Such outstanding scientists as professor R.F. Nagaev and professor K. Sh. Khodzhaev grew up there among many other talented young people. The main scientific results of that period were summarized in the fundamental book "Synchronization of Dynamical Systems" [2], which is considered, in a certain sense, an encyclopaedia of methods and results in the area of self-synchronization.

A series of papers conceptualizing mathematical methods utilized for the development of the selfsynchronization theory was published in 1970s. These ideas had led to the book [3], which Ilya Blekhman wrote together with A.D. Myshkis and Ya.G. Panovko. It gave rise to intensive interdisciplinary and philosophical discussions on the relationship between the rigorousness of mathematical methods used in the applied sciences and the accuracy/adequateness of the mathematical models of real technical and natural objects, systems, and processes. This book was translted in German [4] and reissued several times [5-8].

Further analysis of various results in nonlinear dynamics, including the problem of vibration-induced transportation, motivated Blekhman to suggest the method of direct separation of motions [30], which became the main mathematical approach for developing a new section of nonlinear dynamics, vibrational mechanics. Professor Eugen B. Kremer (currently living and working in Germany) should be mentioned here among other people who joined Blekhman's department in that decade.

In 1970s, Ilya Blekhman also got acquainted with V.N. Chelomei, the eminent engineer and the leader in developing of space flight missiles. (In 1960s, the Chelomei's team had designed the "Proton"-missiles that are still used in various space flight programs sixty years later.) The contact was initiated through the joint work on the unique in its depth and encyclopaedic in its coverage handbook "Vibrations in Engineering" [9]. On the other hand, discussions with Chelomei gave professor Blekhman an insight to the problems arising in space research, which were new to him. Due to the specific features of space research, many results in this area remain top secret even nowadays.

Regular discussions with professor V.V. Beletsky (Blekhman's good friend since their youth) facilitated Blekhman's interest in the celestial mechanics. It gave him a new impulse for understanding universal character of the self-synchronization tendency. Many Blekhman's friends remember his inspiring stories about synchronization of rotations and orbital revolutions of planets in the solar system and about the mystery of Venus (the only planet rotating in the opposite direction compared to others). He had summarized these ideas and concepts in the book "Synchronization in Science and Technology". First the book appeared in Russian and English in 1980s and then was reissued several times [10-12]. An excellent popularizing book "What vibration can do? On the vibrational mechanics and vibrational technology" appeared in the same decade [13]. The last book doesn't presume any special readers' knowledge exceeding the secondary school level. It has inspired at least two generations to think about astonishing behaviour of everyday objects subjected to deliberate vibrations.

A bunch of talented young researchers joined Blekhman's team in the 80s. His scientific "school" was flourishing and its perspectives seemed to be excellent. However, the political turbulences of the late 80 s and early 90 s changed the situation. Governmental financial support of research was nearly cancelled. The Iron Curtain disappeared, and people from the former Soviet Union got an opportunity to go abroad. In a few years almost all young Blekhman's scholars left Russia. Today they are successful in various countries, including the USA, Canada, Germany, Denmark, Israel and even New Zeeland. Blekhman himself also got the opportunity to visit other countries. Beginning with the ICTAM 1992, he received numerous invitations from the leading universities in all continents. He gave lectures at MIT and 

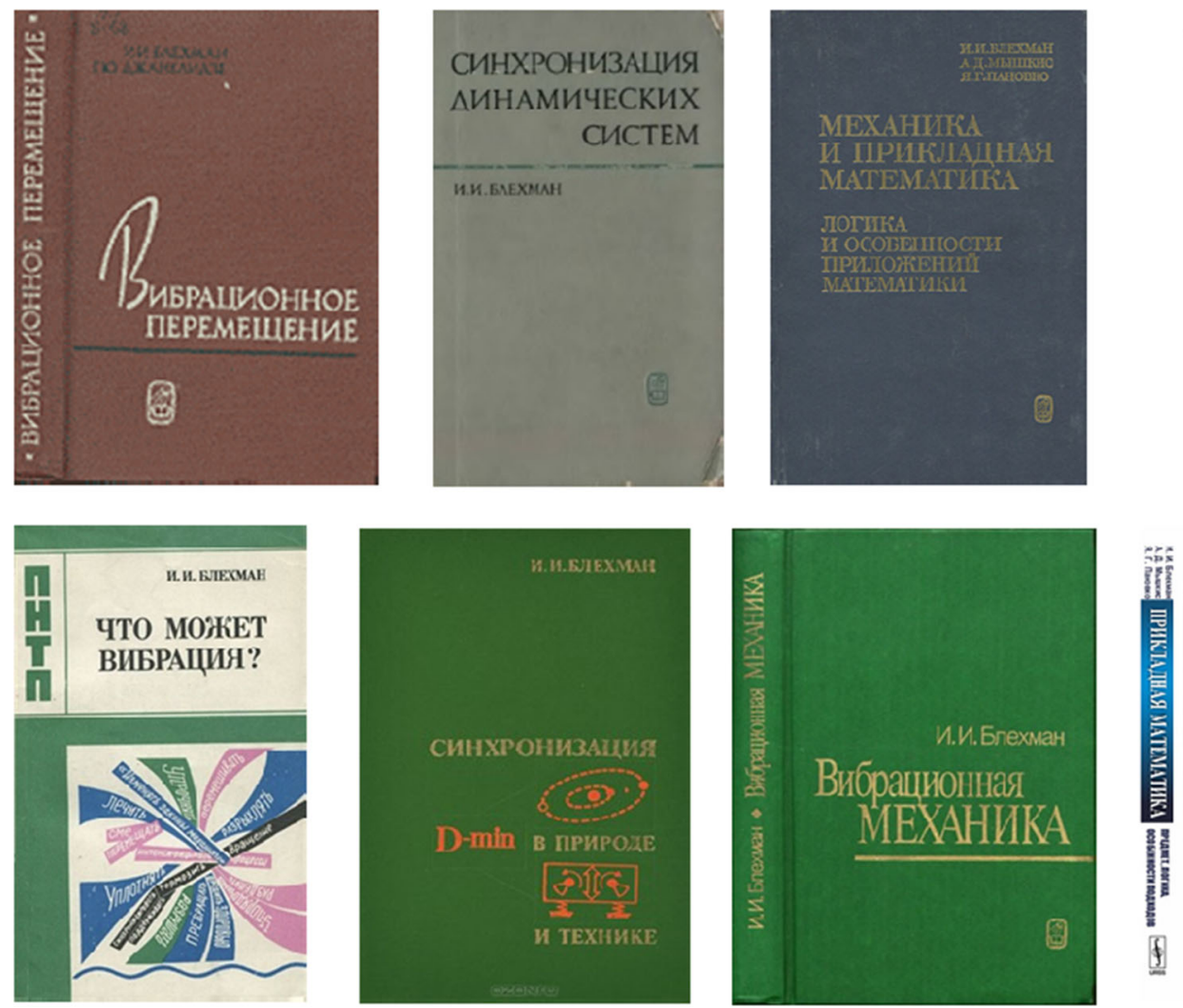

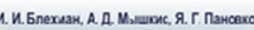

ПРИКЛАДНАЯ

MATEMATИКА пРЕДМЕт

ЛОГИКА

ОСОБЕННОСТИ

ПОДКОДОВ

С примерами из механики<smiles>[CH]=C</smiles>
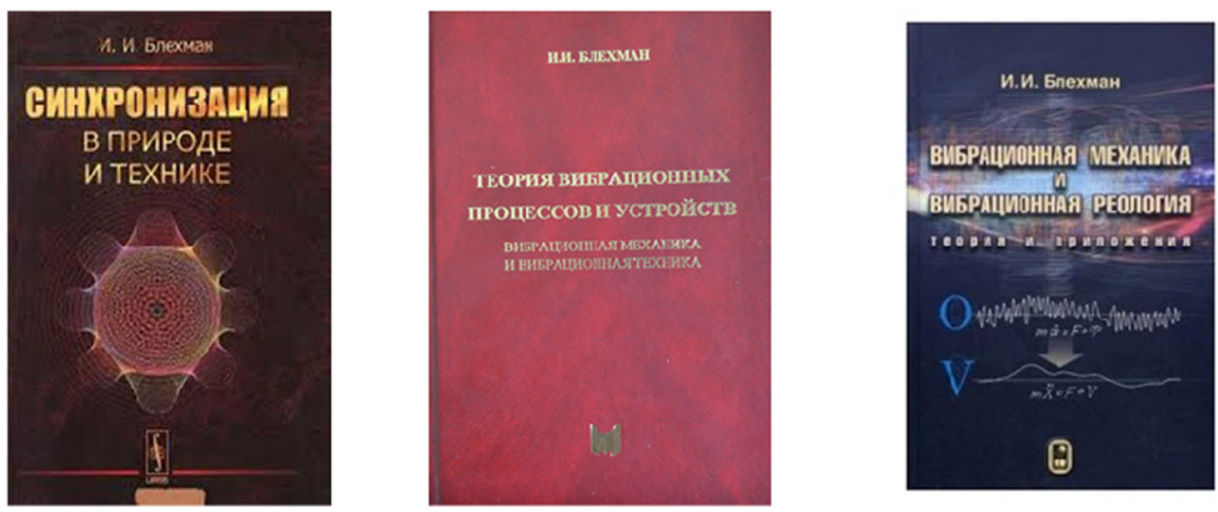

Fig. 1 Books written by Ilya I. Blekhman published in Russian

at the top universities of the UK, Germany, Poland, Brazil and other countries. His collaboration with the Technical University of Denmark in Lyngby was especially fruitful. Under the influence of Blekhman's lectures on vibrational mechanics given in 1996 [14], professor Jon J. Thomsen had established a whole research group there.

The framework of vibrational mechanics had been finalized in early $90 \mathrm{~s}$ as a generalization of the enormous experience of prof. Ilya Blekhman and his scholars obtained over five decades. It enables to analyse and synthesize various machines and processes utilizing vibrations for achieving technological results. The concept had been formulated in full in books [15, 16]. Later, numerous scientists from different countries continued developing the concept. The corresponding results were published in various collections of selected papers [17-19] edited by 
Blekhman and appeared with his active participation and support. The concept of vibrational rheology as a scientific branch describing behaviour of materials and their mixtures under the influence of vibration was also formulated at that time. On the one hand, these investigations allowed explaining such phenomena as limnological catastrophes (for example at the Nyos lake in Cameroon) and developing technological solutions to avoid them. On the other hand, an approach for injecting bubbles into fluids and controlling their position was suggested and realized. New scholars and collaborators supported prof. Blekhman in these explorations. Dr. Sc. V.B. Vasil'kov and Dr. Sc. V.S. Sorokin should be mentioned here as the most outstanding scientists. The books [20] published in 2013 and [21] published in 2018 summarized the main results of their studies. (The reference list in [20] contains 894 titles demonstrating the wide dissemination of the vibrational mechanics in science and technology.)

International recognition of Blekhman's merits was expressed by numerous national and international awards. Among others we mention:

- Prize of the Russian Federation' Government (1998, Russia)

- Alexander von Humboldt Prize (1999, Germany)

- Al-Khwarizmi Prize (2000, Iran)

- P.L. Chebyshev Prize (2009, Russia)

During his long scientific life, prof. Blekhman has written 14 books (Figs. 1,2) and more than 400 papers, as well as registered more than 50 patents and 3 scientific discoveries. He has guided more than 50 $\mathrm{PhD}$ and 11 Doctor of Science candidates to successful completion.

Fig. 2 Books written by Ilya I. Blekhman published in English

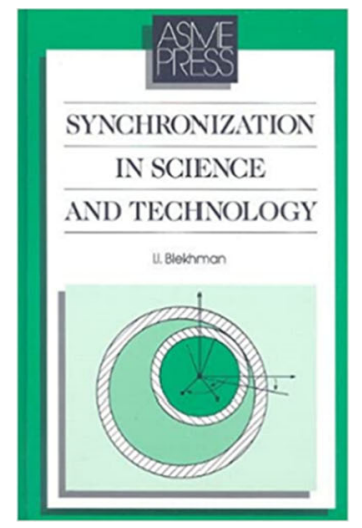

However, Blekhman's impact cannot be reduced to the above numbers. He was so far ahead of his time that we-his contemporaries and scholars-are not able to evaluate the importance of his ideas and their influence on the future generations. It is difficult to believe that Ilya I. Blekhman has left us. But his spirit, way of thinking, generosity and readiness to support new and original ideas, even if they contradict his own visions, will always remain with us. And we in our turn will try to forward it to our own students and successors.

\section{Excerpts from letters written by Ilya. I. Blekhman's friends and colleagues with regard to his death}

Professor Konstantin Lurie, from Worcester Polytechnic Institute, Worcester, MA, describes his memory of Professor Blekhman -friend and scientist:

It is beyond belief that Ilya Izrailevich Blekhman is no longer with us. For me, as for all those who adored his scientific discoveries and prophesies going far ahead his time he was of course a great scholar and teacher who woke up your imagination. I am happy to have known him since probably late fifties, first as a beloved student of my father, and later, after becoming more mature, I recognized what was a calibre of this person. I do not think the time is now ripe to fully realize what he did in science; only the future, that he foresaw far and wide with utmost clarity, will pronounce its verdict. What I can (and wish) to do now is to share some reminiscences about Ilya as a long-time friend, a generous and tender person. Life appears to be savage sometimes to people, and Ilya has
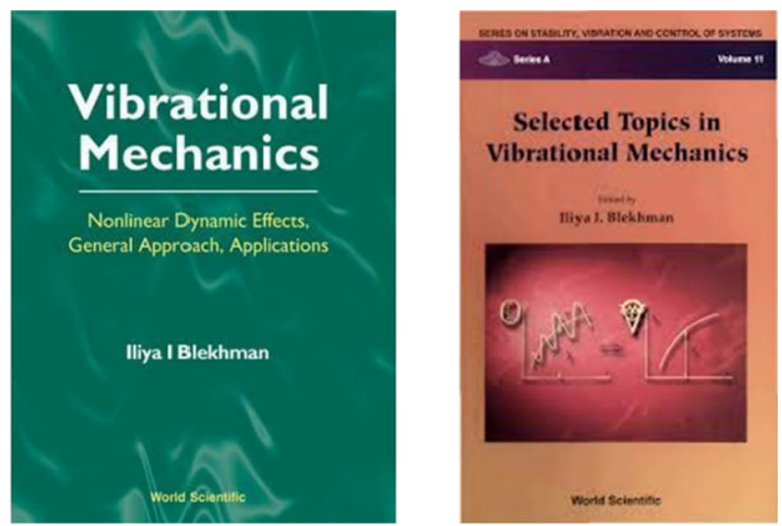
always been there to help. I know that maybe too well. I also know that he had himself gone through terrible ordeals, but his perseverance would overcome.

I have also seen happy moments in his life. Clearly remember two or three weeks 45 years ago that Nina and Ilya spent together with my wife Ella and myself in Nida, Lithuania. A long-time friend, Professor Oleg Savinov, accompanied us, and since then I remember how happy everyone was there. I enjoyed seeing how deeply Ilya loved people. Another memorable occasion took place long after, when we had (at that time almost unbelievable) chance to host Ilya and my lifetime friend Seva Ivanov, then the Head of Dept of Astrophysics, SPb University, at our residence in America. It was a warm evening in August, with falling stars, and our breath taken away as we listened to Ilya's story about planetary resonances. I was watching him, and now realize that I have seen personification of "starry heavens above me and moral law within me". Both were with him, and this is how he will be remembered.

Professor Isaac Elishakoff from the Florida Atlantic University (USA) wrote:

Allow me to express my deepest condolences on passing away of this great man and scientist! He illuminated nonlinearities for decades to the entire world! I met him in Udine some 20 years ago. His lectures were met with applauds and appreciation due to his sage wisdom. May his memory be for blessing!

Professor Giuseppe Rega from the Sapienza University of Rome (Italy) wrote:

I am very sorry to hear of the passing away of Professor Blekhman. He was an excellent scholar, a great educator, a prominent inventor and engineer, a man of great imagination and kindness, who marked decades of theoretical and applied mechanics at the RAS Institute for Problems of Mechanical Engineering, St. Petersburg. He was also a lively and nice person whom, unluckily, I had the pleasure to meet too few times in Russia and abroad (Fig. 3).

Professor Walter Lacarbonara of Sapienza University of Rome remembers the pleasant moments in a few meetings with Professor Blekhman during scientific conferences such as APM (Advanced Problems in Mechanics) in Repino, Russia. He wrote: "I met Prof. Blekhman a few times and was lucky to discuss with him about perturbation methods. I was truly impressed by the depth of his thinking process and his knowledge of nonlinear system dynamics. He could uniquely shift between the physical knowledge and the mathematical intricacies. His kindness and humbleness went never unnoticed".

Professor Vladimir Babitsky from the Loughborough University (UK) wrote:

Ilya Blekhman, an outstanding specialist, an original researcher, an innovator, a tireless scientist, a benevolent and tactful educator, a noble and bright person, passed away. He left, leaving a rich scientific heritage, talented disciples, numerous followers. Having already shown his outstanding professional qualities in his youth, Prof. Blekhman became for many years the unofficial coordinator of vibration researchers in the country, developing new directions, discovering important applications, attracting and inspiring promising researchers. Alien to any manifestation of arrogance, he always remained a kind mentor, advisor and friend for everyone, ready to support any interesting initiative, bringing his vision to it. Each communication with him left a warm feeling of sincere and unchanging benevolence, inspiring support, great optimism and love of life. This is how he will remain forever in the memory of everyone who knew him.

Professor Katica (Stevanovic') Hedrih from the Mathematical Institute of Serbian Academy of Science and Arts remembers numerous meetings with Professor Blekhman at scientific gatherings organized by the International Union of Theoretical and Applied Mechanics (IUTAM) and the European Society of Mechanics (EUROMECH), as well as the Russian Academy of Sciences and the Academy of Nonlinear Sciences in Moscow. After the Yugoslav Congress of Mechanics in Serbia in 1997 in Vrnjačka Banja, she had the pleasure to be his guide in visiting Belgrade. The most memorable memories from the meeting with Professor Blekhman date back to 2000 from St. Petersburg. Control Oscillations and Chaos-COC 2000 was held there, organized by Academician F.L. Chernousko and A.I. Fradkov, under the auspices of IEEE, CSS, IUTAM, SPICS, St. Petersburg, Inst. for Problems of Mech. Eng. of RAS, 2000. Professor Blekhman took professor Hedrih to see the première of the ballet "Swan Lake" with the music of Pyotr Ilyich Tchaikovsky at the Mariinsky Theater. For Professor Hedrih it was an unforgettable magical experience, both a visit to the Mariinsky Theater and watching P.I. Tchaikovsky's ballet performed by important artists from the Russian Federation. This happens to foreign 


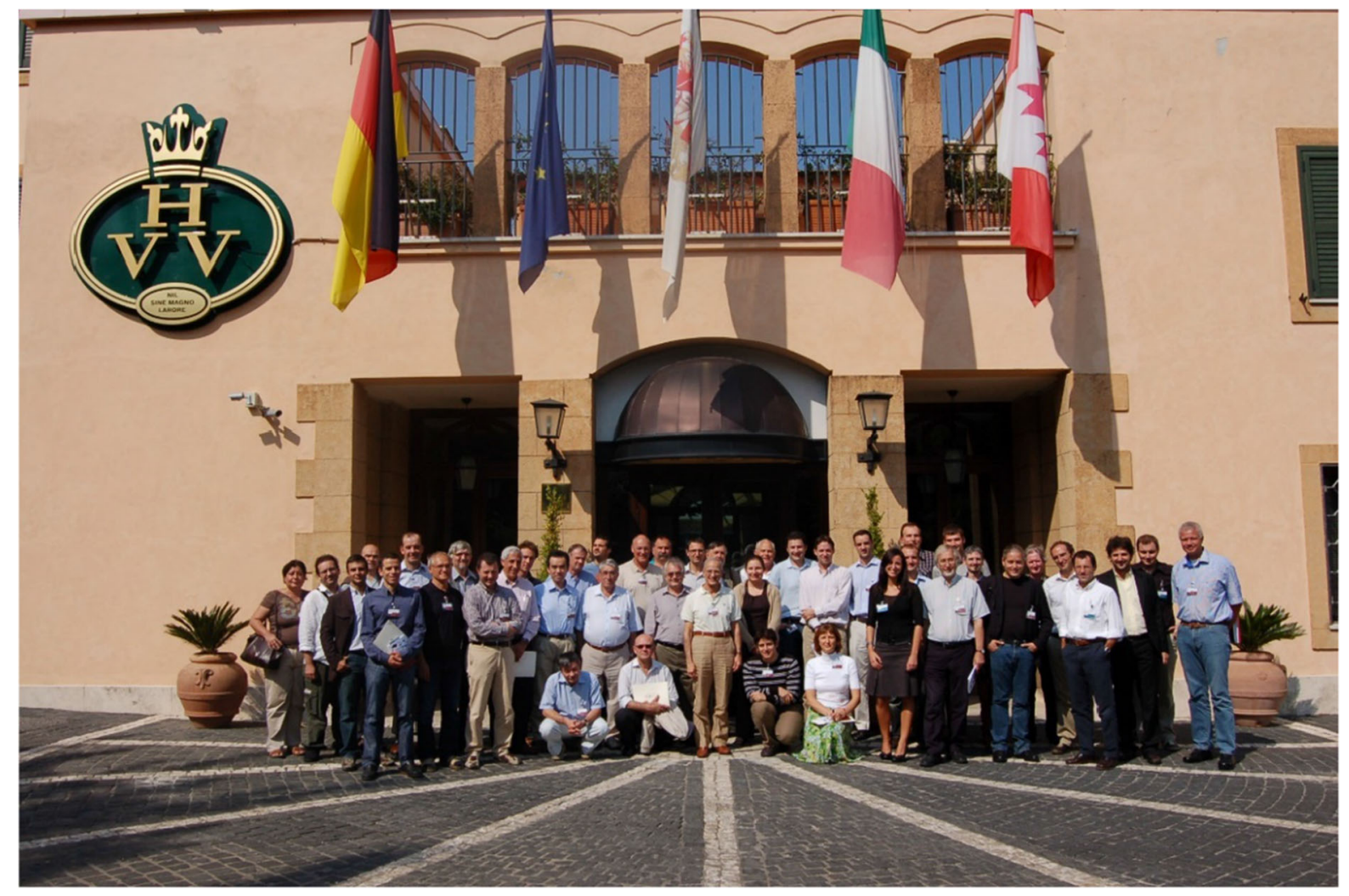

Fig. 3 Participants of the EUROMECH Clloquium 503 "Nonlinear Normal Modes, Dimension Reduction and Localization in Vibrating Systems", Frascati, Italy, 2009, organized by Giuseppe Rega and Alexander Vakakis. In the group picture,

scientists once in a lifetime, or never. Professor Blekhman knew how to show that Russia is very rich in art, and not only in science, to which he himself gave top scientific contributions.

Professor Hedrih also remembers the Collection of Abstracts of the scientific conference "Asymptotic in Mechanics, St. Petersburg 1996”, which she received a decade later from Professor Blekhman. The organizers of the conference were well-known scientists, Academician Yuri Alekseevich Mitropolski from Kiev and Professor Ali Nayfeh from Virginia Tech from USA, and the conference was held at the Saint Petersburg State Marine Technical University. In 2005, Professor Blekhman sent an e-mail to Prof. Hedrih asking for an abstract of the lecture given at that conference. She replied that she could only send him a word file and that she did not know if the abstract had been published at all. Shortly afterwards, she received a copy of the Proceedings with his
Prof. Blekhman is clearly recognizable in the first row of standing up people, in between Hiroshi Yabuno and Yoannis Georgiou

dedications, which she was very happy about. Professor Blekhman obtained the original of the Proceedings and sent it to her. This happened almost one decade later, and the dedication written in the first page of the Proceedings was a wonderful sentence, in English translation: "Better to get it later than never (In Russian: Лучие позже, чем никогда)".

The last scientific meeting with Professor Blekhman was at the Boarding School of the Russian Academy of Sciences in Zvenigorod, and the last e-mail he sent her was a New Year's card for 2021.

Professor Tamara Nestorovic, from Ruhr-Universität Bochum, describes her memory of Professor Blekhman as follows:

I met Prof. Blekhman once in Magdeburg, during my $\mathrm{PhD}$ at that time, but I knew about him even before that. It was in 2000, when after having finished my magister degree at the University in Niš, Serbia, eager for reaching new research horizons I got a suggestion 
from Prof. Hedrih: "My colleague and an excellent friend, Prof. Blekhman is currently in Germany, Magdeburg, there they are searching for a $\mathrm{PhD}$ candidate, you could send him your CV... “ And I did it. Even not knowing me at all, Prof. Blekhman had considered my $\mathrm{CV}$, forwarded it, and soon an invitation came from Prof. Urlih Gabbert from Otto-vonGuericke University in Magdeburg-I could come to give a talk at the University and perform research within a short stay in Magdeburg (one to three months). I decided to spend there a month and that's how it all started. After that I was accepted for $\mathrm{PhD}$ and stayed there in Magdeburg for several years. I was honoured to have had an opportunity to meet Prof.Ilya Blekhman once during his visit in Magdeburg. I cannot remember exactly the year, but I do remember his gentlemen gesture very well-on that March 8th, International Women's Day, all female employees of the Institute got a rose as a present from Prof. Blekhman. ...Years have passed, I have moved to another city in Germany, Bochum, where I got my University Professorship, where I live and work now... But I always remember how it all began, how I came there... and I know-without Prof. Blekhman probably it would not have happened.

Professor Klaus Zimmermann and Dr.Sc. Igor Zeidis from the Technical University of Ilmenau (Germany) wrote:

We made acquaintance with Ilya Izrailevich rather closely when he was visiting Germany as a Humboldt Prize laureate, although one of us had known him previously.

Ilya Izrailevich was a wonderful person. First of all, he attracted us with his natural intelligence and benevolence. In addition, he had an extreme erudition in terms of general culture. As to mechanics, his understanding of the subject matter was amazing. It seemed that he did not need any equations and could give an answer in advance. It is commonly known that Ilya Izrailevich is in fact the creator of the entire branch of science, vibrational mechanics. His book «Applied Mathematics: Subject Matter, Logic, and Methodological Features», co-authored with an outstanding mathematician A.D. Myshkis and a mechanician Ya.G. Panovko, greatly influenced several generations of researchers. In our opinion, it was the first book in which the philosophy of applied mathematics was presented. This philosophy has not lost its topicality today. We are proud that we have had happiness to meet such a wonderful person and to be friends with him.

Professor Friedrich Pfeiffer from the Technical University of Munich (Germany) wrote:

Professor Ilya Blekhman died in February 2021 from Corona. He has been an outstanding representative of Russian science with an extraordinary body of contributions in the fields of mechanics and applied mathematics, but also in other areas of applied physics. With him a great old man of science passed away, internationally well-known and acknowledged. His brilliant ideas will survive and influence modern research. Professor Blekhman was an impressive personality, his charisma got him attention, everywhere and for any situation. He was a charming person and a nice colleague, always positive and constructive, always with good ideas and remarkable position. I personally had the pleasure to meet and support him on the occasion of his stay in Ilmenau as a Humboldt awardee and later on during various international Conferences. The scientific community will not forget him, and I personally have lost an outstanding colleague.

Professor Lutz Sperling from the Otto-von-Guericke University Magdeburg (Germany) wrote:

The first $\mathrm{PhD}$ thesis on self-synchronization of unbalanced rotors had been successfully defended at the Institute of Mechanics of the Otto-von-GuerickeUniversity Magdeburg in 1966. The research was strongly based on the publications by Blekhman and his colleagues. In his thesis, Lutz Sperling had introduced the harmonic influence coefficients to simplify calculation of the existence and stability conditions of synchronous movements. This approach enabled him to reduce the problem for linear carrier systems to solving of a standard linear oscillation problem. The advantage of the proposed approach had been demonstrated for various applications. This result was explicitly appreciated in the subsequent Blekhman's publications.

The first written contact between Blekhman and Sperling was established in 1967, and the first personal contact happened in 1973. These collaborations have been intensified through mutual visits since 1997. For example, professor Sperling visited numerous summer schools in St.-Petersburg/Repino from 1998 on. In 1999, professor Blekhman agreed to contribute to Falk Merten's PhD thesis defence as a reviewer and an examiner. As Ilya Blekhman was honoured with the 
prestigious Humboldt award in 2000, he spent three months at the professor Sperling's chair (Vibrations and Engineering Dynamics) in Magdeburg. He also went to stay with professor Hans Dresig at the Technical University in Chemnitz, for three months. The joint research during that period resulted in publishing five collaborative papers on synchronization of systems with internal degrees of freedom. Other activities in Magdeburg, in that area, included diverse applications of self-synchronization, simplification of the corresponding approaches for practical purposes, and the studies of synchronization-based self-balancing systems. Due to prof. Blekhman's recommendation, Dr. Boris Ryzhik joined the Institute of Mechanics in Magdeburg in 2001; his scientific activity in Magdeburg has been very successful.

Professor Ilya Blekhman was for me and my former employees a close friend and teacher. His impact on my professional life was formative and I remained in contact with him until the last weeks of his life. Together with my wife we used to enjoy his hospitality in St.Petersburg and Repino and were happy to be his hosts in Magdeburg. I'll never forget our numerous (not only professional) conversations and joint trips, and cultural highlights.

Professor Blekhman's death has completed his extraordinary fruitful and fulfilled life as a scientist. His memory will remain gratefully cherished.

Dr.Sc. Eugen Kremer from the Schaeffler Group (Germany) wrote:

I knew Professor Blekhman for almost fifty years. For twenty-seven years, I worked in his department, and then, we maintained personal and professional contacts and participated in joint research projects. In preparation for my first meeting with him as a thirdyear student, I began reading his monograph "Synchronization of Dynamic Systems". It fascinated me from the very first pages with examples of synchronization: alpha rhythms of the brain, fireflies, perhaps telepathy, synchronous applauses. His ability to admire the diversity and unity of nature inspired his listeners and readers and motivated them to go further to the equations, to appreciate their original beauty as well. This "scientific-romantic" vision of the world, his phenomenal erudition and breadth of scientific interests were joined with such deep analysis of each individual problem which would have been impossible without his impeccable mathematical technique and amazing intuition. For me, as probably for many others, Professor Blekhman was not only the author of the priceless scientific works, discoveries, inventions, and brilliant world-known monographs, but also a moral guide, a man, under whose influence the views on life and on our profession were formed. His respect for engineering labour and his ability to speak the same language with designers allowed his theories and discoveries to turn into many original real machines. He tried to pass on his students this view of the purpose of the mechanical scientist - to reach for the stars, but to stand on the ground. Professor Blekhman was a man of infinite charm. His kindness, generosity, selfless desire to help people and a mild sense of humor, which did not leave him even in difficult moments of life, will be remembered forever by those who had the happiness of knowing him.

Professor Jon Juel Thomsen, Technical University of Denmark wrote:

In many ways prof. Blekhman's mind and actions changed the path and perspectives of my own life. I have so many good and exciting memories and learning experiences associated with him, including also with his friends and colleagues. He opened my eyes to a whole new field of research and was so greatly inspiring, not least during his research visits at my dept. These began after my first encounter in the 1996 with his book "Vibrational Mechanics", in Russian, which I didn't understood. But nevertheless just from the figures and equations found so irresistibly attractive and mind stimulating that I saw no other way than inviting prof. Blekhman to give a $\mathrm{PhD}$ course at my university to explain this strange topic. That spun off a lot of scientific activity in the years to come, also by my students and close collaborators, much of it in cooperation with or inspired directly by prof. Blekhman. Still today, the "fast vibration" lectures in my course on advanced vibration analysis appear to stir significant student interest. I feel deeply saddened by the passing away of prof. Blekhman. But what a fantastic life that ended, what a huge footprint to leave. I feel sure he will stay alive in the minds of so many people for very long times-not just for us who was lucky enough to get to know him personally, but also for coming generations of students of his huge and widespread scientific production. His way of seeing, formulating, solving, and communicating scientific problems will always stand out to me as an ideal worth striving for. To me his spirit seems permanently 
wandering around, I feel so deeply thankful and privileged for having been in touch with it.

Professor Sergey Sorokin, Aalborg University, Denmark wrote:

It has been a severe personal blow for me to learn that Professor Ilya Izrailevich Blekhman passed away. I've known him since mid-eighties and he has always epitomized for me virtues of great scholar, excellent teacher, and admirable person.

His contribution to nonlinear mechanics is outstanding, and its full-scale appreciation is yet to come. However, already now it is undisputable that Ilya Izrailevich has become a founder of a novel direction of its development, Vibrational Mechanics. He has established the 'shkola' (school) of Vibrational Mechanics and his former research students and colleagues continue to elaborate on its concepts and ideas worldwide, Russia, USA, Germany, Denmark, New Zealand, Israel being examples, which have come to my mind straightaway. Such a recognition is, probably, the best token of acknowledgement a scientist can receive.

Professor Blekhman was a perfect teacher and, when I headed the Department of Engineering Mechanics of the State Marine Technical University of St. Petersburg, it was a privilege to obtain his consent to give lectures there. Thanks to his enthusiasm and engagement in the research topics he dealt with, his lectures for undergraduates and for research students were always a great success. On top of that, not only me, but many other relatively mature researchers were fascinated by the elegance and physical relevance of Vibrational Mechanics and, inspired by Ilya Izrailevich, began to use its tools in own research.

Finally, I'd like to say that Ilya Izrailevich was the finest example of brilliant personality. His irreproachable delicacy and generosity-whenever in formal or informal context - evoked respect of everybody who met him. Young research students were always much inspired by the constructive and encouraging feedback from Professor Blekhman in the course of seminars held in his cosy little office at Mekhanobr. I also remember endless discussions of non-trivial effects of vibrations (always 'served' with cookies and strong black tea), which I had with Ilya Izrailevich in his office each time I visited St. Petersburg from Denmark. Of course, it was a pleasure to share other gatherings with him, and I will always carry in my heart the precious reminiscences of this wonderful person.

Dr.Sc. Vladislav Sorokin from Auckland University (New Zeeland) wrote:

I was fortunate to work with professor Blekhman from 2003 (when I was only 15 years of age, in the last year of my high school education) and up till his death. His passion for science and kind personality had a strong effect on myself, and, in the end, induced me to choose academic career. I was always very much impressed by the creativity and flexibility of his mind and believe that, if not for Covid-19, he could still contribute a lot to science. On the 3rd of February 2021 we have lost not only one of the greatest scholars in Nonlinear Dynamics, but also a personality that others can only strive to be.

Professor Zalmen Filer (Ukraine, Israel) wrote:

Professor Blekhman's importance for my professional life can be hardly overvalued. We met each other in 1965, after he had invited me and my colleagues from Donbass to visit Mekhanobr, to take a look at the vibration test rig with two unbalanced exciters. While I was preparing my $\mathrm{PhD}$ defence in the Institute of Mathematics of the Ukrainian Academy of Sciences, prof. V.N. Koshlyakov suggested inviting prof. Blekhman as a reviewer and an examiner. It made me very happy, because Blekhman was the first scientist interested in my research. During my defence in 1966 he said, "Like Einstein was the first one who had fused space and time, had Zalmen Filer fused a vibration machine with its engine". This joke had enlightened the formal atmosphere in the audience.

Since that time, my whole professional life has been strongly influenced by Ilya Blekhman. Our last meeting took place in Sevastopol in 1991. Our correspondence was interesting and informative. The communication became very special after 2019 when, due to the eye disease, Ilya Blekhman delegated the correspondence to his son. May the blessed memory of this great scientist and excellent person live forever!

Professor Alexander Fidlin from the Karlsruhe Institute of Technology (Germany) wrote:

For the first time I had met Ulya Izrailevich Blekhman during summer vacations in Druskininkai (Lithuania) in 1977. I just had turned 12 years old. Nobody could imagine at that time that this acquaintance would have determined my professional life to a very large extent. I was astonished that summer to observe that every evening without any exception, 
being on vacation with his wife and daughter (she was also 12), he went to the table, distributed some books and papers there, and wrote fascinating and mysterious formulas.

It was Blekhman who three years later advised me to study mechanics at the Polytechnic University, suggesting to choose the professor Lurie's chair for my specialization. After the next four years had passed, he offered me to think about a scientific problem, which then became the topic of my diploma thesis. Six years of working in Blekhman's department at Mekhanobr had shaped me as a scientist, giving me the invaluable experience of creative atmosphere, full of friendship, mutual support and exchange of ideas, but free of any internal competition. It was Ilya Izrailevich who had created this fruitful atmosphere in his department.

Professor Blekhman was extremely generous with respect to scientific concepts and results. For example, at the end of $1990 \mathrm{~s}$, as I was already living in Germany, I had sent him a draft of a paper on mathematical justification of the method of direct separation of motions. The paper showed that for a certain class of problems this method must be seriously modified. Ilya Izrailevich had fully supported publication of this paper and then advertised these results during the next conferences. He also used these occasions to introduce me to Jon Juel Thomsen, Anatoly Neishtadt (from the Loughborough University, UK), and Hans Dresig (Technical University Chemnitz, Germany). Collaboration with them was extraordinarily productive throughout the following decades.

Professor Blekhman visited Germany many times and met my PhD students. He was always pleased about their enthusiasm and original ideas, contributing to deeper understanding of the concepts of nonlinear dynamics and their applications to solving complex engineering problems.

It is unbearable to believe that Ilya Izrailevich Blekhman is not with us anymore and it is impossible to call him to share joy and sorrow, success and hurdles, happiness, and sadness. But actually it is not true. He is still with us; his spirit remains alive in his scholars and their own students, and in all those who was lucky to get in touch with this astonishing person and ingenious scientist!

\section{References}

\section{Books}

1. Blekhman, I.I., Dzanelidze, G.Y.: Vibrational Displacement. Nauka, Moscow (1964). (in Russian)

2. Blekhman, I.I.: Synchronization of Dynamic Systems. Nauka, Moscow (1971). (in Russian)

3. Blekhman, I.I., Myshkis, A.D., Panovko, Y.G.: Applied Mathematics: Object Logic and Peculiarities of the Approach. Naukova Dumka, Kiev (1976). (in Russian)

4. Blekhman, I.I., Myshkis, A.D., Panovko, Y.G.: Angewandte Mathematik (Gegenstand, Logik, Besonderheiten). Veb Deutscher Verlag der Wissenschaften, Berlin (1989). (in German)

5. Blekhman, I.I., Myshkis, A.D., Panovko, Y.G.: Mechanics and Applied mathematics: Logic and Peculiarities of Applications. Nauka, Moscow (1983). (in Russian)

6. Second issue - 1990. (in Russian)

7. Blekhman, I.I., Myshkis, A.D., Panovko, Y.G.: Applied Mathematics: Object, Logic and peculiarities of the approach. With Mechanical Examples (3rd Issue). KomKniga, Moscow, (2005). (in Russian)

8. Fourth issue - LKI Publishing, (2007). (in Russian)

9. Blekhman, I.I.: Vibrations in Eingineering. In: Handbook in 6 Volumes. Vol. 2 Vibrations of Nonlinear Mechanical Systems. Mashinostroenie, Moscow, (1978-1981) (in Russian)

10. Blekhman, I.I.: Synchronization in Science and Technology. Nauka, Moscow (1981). (in Russian)

11. Blekhman, I.I.: Synchronization in Science and Technology. ASME Press, New York (1988)

12. Blekhman, I.I.: Synchronization in Nature and Technology. LENAND, Moscow (2015). (in Russian)

13. Blekhman, I.I.: What can Vibration do? On Vibrational Mechanics and Vibrational Technology. Nauka, Moscow, (1988). (in Russian)

14. Blekhman, I.I.: Vibrational Mechanics. Fizmatgiz, Moscow (1994). (in Russian)

15. Blekhman, I.I.: Vibrational Mechanics. Nonlinear Dynamic Effects, General Approach, Applications. World Scientific Publishing Co., Singapore (2000)

16. Blekhman I.I.: Vibrational Mechanics. Lecture notes for session IV of the $\mathrm{PhD}$ course "Vibrations and Stability, Advanced Analysis and Synthesis". Technical University of Denmark, (1996).

17. Blekhman, I.I., Fradkiv, A.L.: Control of Mechatronic Vibrational Devices. Nauka, St.-Petersburg(2001). (in Russian)

18. Blekhman, I.I.: Selected Topics in Vibrational Mechanics. World Scientific Publishing Co., Singapore (2004)

19. Adhikari S., Bartoli I., Blekhman I.I., Calio I. et al.: Mechanical Vibration: Where do we stand? In: Elishakoff, I. (ed.) Springer, Wien, New York, (2006)

20. Blekhman, I.I.: Theory of Vibrational Processes and Devices Vibrational Mechanics and Vibrational Technology. Publishing House Ruda I Metally, St.-Petersburg, (2013). (in Russian) 
21. Blekhman, I.I.: Vibrational Mechanics and Vibrational Rheology (Theory and Applications. FIZMATLIT, Moscow (2018). (in Russian)

\section{Selected Journal Papers (all in Russian)}

22. Блехман И.И. Исследование процесса вибросепарации и вибротранспортировки. Инженерный сборник, 1952, Т. XI, c. $35-78$

23. Блехман И.И. Самосинхронизация вибраторов нек, оторых вибрационных машин. Инженерный сборник, 1953, T. XVI, c. 49-72

24. Блехман И.И. Исследование процесса вибрационной забивки свай и шпунтов. Инженерный сборник, 1954, Т. XIX, c. $55-64$.

25. Блехман И.И. Врашение неуравновешенного ротора, обусловленное гармоническими колебаниями его оси. Известия АН СССР (ОТН), 1954, №8, с. 79-94

26. Блехман И.И., Джанелидзе Г.Ю. Динамика регуля, тора Буасса-Сарда. Известия АН СССР (ОТН), 1955, № 10 , c. $48-59$
27. Блехман И.И. К вопросу об устойчивости перодических решений квазилинейных неавтономных систем со многими степенями свободы. Доклады АН СССР, 1955, Т $104,^{\circ} 6$, с. $809-812$

28. Блехман И.И. Об устойчивости перодических решений квазилинейных автономных систем со многими степенями свободы. Доклады АН СССР, 1957, Т 112, №2 2, с. 183-186

29. Блехман И.И. Теория вибросепараторов и её связь с теорией некоторых других новых вибрационных машин. В сб. науч. тр. Механика и расчет машин вибрационного типа, М.: Изд. АН СССР, 1957.

30. Блехман И.И.Метод прямого разделения движений в задачах о действии вибрации на нелинейные механические системы. Известия АН СССР, Механика твердого тела, 1976, №6, с. 13-27

Publisher's Note Springer Nature remains neutral with regard to jurisdictional claims in published maps and institutional affiliations. 